Relations industrielles

Industrial Relations

\title{
Labor Relations: Development, Structure, Process, (Revised Edition), by John A. Fossum, Dallas, Business Publications, Inc., 1982, 521 pp., ISBN 0-256-02688-2.
}

\section{Kurt Wetzel}

Volume 37, numéro 4, 1982

URI : https://id.erudit.org/iderudit/029315ar

DOI : https://doi.org/10.7202/029315ar

Aller au sommaire du numéro

Éditeur(s)

Département des relations industrielles de l'Université Laval

ISSN

0034-379X (imprimé)

1703-8138 (numérique)

Découvrir la revue

Citer ce compte rendu

Wetzel, K. (1982). Compte rendu de [Labor Relations: Development, Structure, Process, (Revised Edition), by John A. Fossum, Dallas, Business Publications, Inc., 1982, 521 pp., ISBN 0-256-02688-2.] Relations industrielles / Industrial Relations, 37(4), 968-969. https://doi.org/10.7202/029315ar

Tous droits réservés (C) Département des relations industrielles de l'Université Laval, 1982
Ce document est protégé par la loi sur le droit d'auteur. L’utilisation des services d’Érudit (y compris la reproduction) est assujettie à sa politique d'utilisation que vous pouvez consulter en ligne.

https://apropos.erudit.org/fr/usagers/politique-dutilisation/ 
1970 à 1980. Il s'agit alors de deux documents de travail permettant, dans un premier temps, de repérer les sentences arbitrales traitant de telle ou de telle autre question et par la suite, de vérifier, à l'aide des résumés, quelles sentences semblent fournir des éléments de réponse à la question soulevée.

Le premier document comprend trois index de repérage de ces sentences arbitrales: par thème, par les noms des arbitres et par les entreprises. Ainsi qu'on le comprend facilement, l'index analytique par thème est de loin le plus important. Contrairement aux S.A.G. où l'index annuel pouvait varier d'année en année, nous avons maintenant un index unique pour repérer cette somme de 2.500 sentences arbitrales.

Le recueil des résumés de sentences suit l'ordre numérique des décisions ce qui rend très facile le repérage des résumés recherchés. Notons qu'il s'agit généralement d'un rappel succinct des résumés que l'on retrouve déjà au S.A.G. Pour cette double raison, il va sans dire que la recherche ne peut être terminée après cette double consultation.

Ces résumés ne permettent nullement de connaître le particularisme de la disposition de la convention collective étudiée par l'arbitre, ni les éléments de preuve dont il disposait et ni les nuances, réserves ou distinctions qui y sont faites. Les procureurs des parties et les arbitres devront donc, au terme d'une présélection rapide que permettent ces nouveaux outils de travail, vérifier le contenu réel des sentences alors retenues.

\section{Fernand MORIN}

Université Laval

Labor Relations: Development, Structure, Process, (Revised Edition), by John A. Fossum, Dallas, Business Publications, Inc., 1982, 521 pp., ISBN 0-256-02688-2.

Fossum's textbook attempts to integrate the institutional approach to labour relations with the more recent contributions emanating from the field of organizational behavior. The title's emphasis on the development, structure and process of American labour relations indicates the author's recognition that he has assumed a worthwhile but sizeable undertaking.

The development section is comprised of three chapters. Two address the history of the American labour movement, and the third consists of a compendium of federal legislation. The history chapters provide a prosaic synopsis of the high points. The reason becomes evident if one examines the footnotes, which are conveniently placed at the bottom of the page, as well as the suggested readings. These sources reveal an undue reliance upon historical surveys rather than material from revealing specialized works.

From the outset, the book makes excessive use of unintegrated tangentially-related inserts that contribute more to its bulk than to its substance. The reader is edified, for existence, by a four-page list of 52 "ways in which (Teamster leader) Dave Beck misused his authority'. The broader issues of union corruption and management complicity are not broached as they should be in a book that endeavors to present a balanced perspective to business school students. A more puzzling inclusion is George Meany's 1979 farewell address, which ends with, "Today the American trade union movement is vital, dynamic, growing. It is strong and unified.",

From development the book moves to structure, i.e. the structure and government of unions, which is dispatched with in a single chapter and a few supplementary pages identifying relevant governmental agencies. This token nod in the direction of structure falls well shy of providing a framework upon which students can base an integrated understanding of industrial relations systems. The essence of the adversarial system of labour management relations and the larger theoretical questions flowing therefrom, which have absorbed some of the better minds in the field, are simply ignored. A book that endeavors to be "a synthesis of some of the best efforts of both the institutional and behavioral research products" and yet bypasses Marx, 
the Webbs, Commons, Perlman, Dunlop, Kerr et al., etc., is devoid of much of the essence of institutionalism.

The body of this book is devoted to process. Chapter 6 provides an excellent discussion of union organizing; the activities of the parties and the Board throughout organizing campaigns, unit determinations and (de)certifications are explained in a way that anticipates student curiousity and puts the informatio into a comprehensible framework. An illuminating discussion of union democracy is also included. Chapters 7-10 deal with bargaining theory, structures and issues. An extensive section on bargaining structure is provided. The author utilizes Walton and McKersie's seminal work to good effect in explaining bargaining subprocesses. A book with such a sharp focus upon process would have benefited from a stronger emphasis upon bargaining strategies and tactics to augment the accompanying simulation case. Chapter 12 introduces the concept of unionmanagement cooperation and outlines approaches which have been made to implement it within and beyond the confines of collective bargaining. The chapter could have been improved through greater use of comparative material.

The final portion of the book is given over to chapters on public sector and healthcare labour relations, equal employment opportunities, and challenges facing collective bargaining, the bulk of which has little applicability to Canada.

Overall, the book is well organized and very readable, making effective use of flow charts to clarify sequencing and contingencies. The work is not encyclopedic; it is, in fact, sketchy in a number of areas. It does present current behavioral research and timely topics. One might have expected that the basic flaw, absence of a strong structure section, to have been remedied in this revision. Since it has not been, the book suffers.

Kurt WETZEL University of Saskatchewan

\section{Les relations patronales-syndicales au Qué-} bec, par Jean Boivin et Jacques Guilbault, Chicoutimi, Gaëtan Morin éditeur, 1982, 309 pp., ISBN 2-89105-087-8.

Il faut être redevable aux deux auteurs d'avoir mis à la disposition des formateurs et des "preneurs de formation», qu'il s'agisse d'étudiants «classiques» ou d'autres, un ouvrage d'initiation dont la nécessité et l'utilité auront déjà été, vraisemblablement, démontrées à l'heure de la parution de la présente note.

Jean Boivin et Jacques Guilbault, en qualifiant d'emblée leur livre comme «un exercice de vulgarisation» visant, par une information le plus simplement exprimée et en même temps substantielle, un large public, expliquent par ce souci le choix du titre du volume, de préférence à celui de relations du travail. Du même coup, étant donné les connotations de l'expression "relations patronales-syndicales», ils mettent leur manuel en perspective historique, vertu cardinale pour introduire à un domaine qui - peut-être plus dans mon pays que dans le leur - engendre, même parmi certains acteurs du système, des malentendus superflus dus au manque de notions d'histoire du mouvement syndical, unies à celle, parallèle du business.

Mais, en faisant leur affaire de la description de l'interaction des partenaires sociaux au Québec, ils ont, dès l'abord, le souci de montrer qu'ils ne prétendent pas couvrir par les seuls rapports collectifs le domaine, plus vaste des relations industrielles. Et il n'est pas étonnant de voir deux professeurs du département qui a, le premier au Québec, me semble-t-il, donné une consistance institutionnelle à l'enseignement de cette multidiscipline (visant à l'interdisciplinarité), rappeler l'importance, non moindre, des sciences du comportement et de la gestion des ressources humaines dans sa structuration et son développement.

Boivin et Guilbault ont raison de dire que tout ce qui est «travail» n'est pas forcément rapportable aux relations industrielles. Certes, la pluridisciplinarité ne signifie guère 